\title{
Clustering of Parkinson's Disease in Southern Israel
}

\author{
Y.O. Herishanu, J.R. Goldsmith, J.M. Abarbanel and Z. Weinbaum
}

\begin{abstract}
On three adjacent kibbutzim (collective rural communities) in the Negev (Southern Israel) 13 parkinsonian patients were found among a population of 592 persons 40 years or older. The clinical picture was not different from that of patients from other areas with idiopathic parkinsonism. Long term residence in the kibbutzim is characteristic of this population. In the past most of the drinking water has been supplied by wells from a common aquifer. From other patients with Parkinson's disease in the Negev, we estimated the age-specific incidence for the region. The incidence is about five times greater in each of these kibbutzim than in the remainder of the Negev. Although associations with rural residence and well water use have been reported elsewhere, clusters of this sort have not been reported. They strongly suggest that a common environmental factor exists.
\end{abstract}

RÉSUMÉ: Agrégation de cas de la maladie de Parkinson dans le sud de l'état d'Israël Nous avons recensé 13 parkinsoniens dans trois kibbutzim (agglomérations rurales collectives) voisins dans le Négev (sud de l'état d'Israël) parmi une population de 592 personnes âgées de 40 ans et plus. Leur tableau clinique n'était pas différent de celui qu'on retrouve chez les patients présentant un parkinsonisme idiopathique dans d'autres régions. Cette population réside dans le kibbutz depuis longtemps. Dans le passé, l'eau potable provenait en majeure partie de puits rejoignant la même nappe phréatique. À partir des données globales pour le Négev, nous avons estimé l'incidence régionale par âge. L'incidence est à peu près de cinq fois supérieure dans chacun de ces kibbutzim que dans le reste du Négev. Même si l'association avec un lieu de résidence rural et la consommation d'eau de puits a été rapportée ailleurs, une telle agrégation de cas n'a pas été rapportée antérieurement. Cette observation suggère fortement qu'un facteur environnemental commun existe dans ces lieux.

Can. J. Neurol. Sci. 1989; 16:402-405

Parkinson's syndrome is a common neurological condition with an incidence varying between 65.6 in Sardinial or 80.6 in Japan $^{2}$ to $164.2 / 100,000$ in Scotland. ${ }^{3}$ The majority of these cases suffer from Parkinson's disease (PD).

In recent years much research has been done to elucidate the factors contributing to the development of this condition. An important limiting factor in this research is the fact that this condition is subclinical for several decades until the first manifestation, most commonly in the seventh decade. Now, prominent scientists in the field believe that environmental factors are involved in the etiology of this disorder, acting on a background of slow, sustained neuronal loss due to advancing age. 4

Epidemiological studies done in different areas of the world showed that Parkinson's disease is more frequent among rural populations and well water supply was proposed as a possible etiological factor.5,6,7 Detection of clusters of parkinsonian patients may help to focus on some environmental factors playing a role in the development of this disease. The aim of this paper is to report an unusual clustering of patients with
Parkinson's disease in several kibbutzim (collective rural communities) concentrated in a limited area of the Negev.

\section{Patients and Methods}

A review of the medical records of the Neurology Outpatient Clinic of Soroka University Medical Center, revealed 156 PD patients alive at October 1st, 1988. Soroka University Medical Center is the single general hospital serving all 250,000 inhabitants of the Negev (Southern Israel); therefore, these patients may be assumed to be virtually all those with clinically manifest PD in the Negev. Of these 156 patients, 13 PD patients live in three adjacent kibbutzim (4-5 km apart) located in the NorthWestern part of the Negev. Two of these kibbutzim (A and B) were settled in 1941-42 and the third (C) in 1948. The first two kibbutzim received their water supply for several years from the same well situated several kilometres to the west and later aquired their own wells. Kibbutz A and B used water from the same aquifer. Kibbutz $C$ has its own well. Kibbutz $A$ is situated

From the Neurology Department (Y.O.H., J.M.A.) and the Epidemiology and Health Services Evaluation Unit (J.R.G., Z.W.) Soroka University Medical Center, Faculty of Health Sciences, Ben Gurion University of the Negev, Beer-Sheva, Israel.

Received February 22, 1989. Accepted in final form August 11, 1989

Reprint requests to: Prof. Yuval O. Herishanu, Department of Neurology, Soroka University Medical Center, POB 151, Beer-Sheva, Israel 
higher than the other two, on sandy, calcium-rich soil, separated from kibbutz B by a gully. Close to the gully old automotive parts were disposed of for many years. In the early sixties these kibbutzim were connected to the National Water Carrier which supplies the water to a large part of the country. These kibbutzim have plantations of oranges, watermelon, cucumbers and potatoes and small factories: metallurgic in kibbutz A utilizing $\mathrm{Mn}, \mathrm{Zn}$ and $\mathrm{Ni}$; plastic in $\mathrm{B}$ and frozen food and ceramics in $\mathrm{C}$.

Demographic data were obtained for each of the 13 patients. The questionnaire included date of birth, country of origin, site and size of the birth place, water supply, date of immigration to Israel (patients who immigrated after 1945 were asked if they were interned in a labor or extermination camp during Nazi occupation), the places in Israel where they have lived and the time spent in each place, agricultural occupation and any contact with chemicals such as organic solvents, fertilizers, pesticides, fungicides, herbicides, manganese or mercury. The patients were also asked about other occupations, hobbies, diseases which afflicted them and their relatives, admissions to hospital or mental institutions, psychiatric conditions, any medications received, smoking habits, system of heating, and accidents in relation to the heating. The same questionnaire was administered to 13 age-matched controls in the cluster, to $32 \mathrm{PD}$ patients in the Negev and to the same number of patients suffering from essential or senile tremor in the Negev.

Clinical data relevant to Parkinson's disease were collected from the files of the Neurology Out-Patient Clinic. Data on the population content and on PD were obtained from 14 kibbutzim and from eight moshavim (villages) in the Negev.

\section{RESULTS}

Four patients live in kibbutz $\mathrm{B}$, three in kibbutz $\mathrm{C}$ and six in kibbutz $A$. Their ages range from 51 to 82 years, and 7 of the 13 are female. Data on the populations of the Negev and the three kibbutzim in the cluster, as well as the estimated age specific prevalence of PD in the Negev and that observed in the cluster

Table 1: Age-specific Prevalence of Parkinson's Disease in the Negev and in a Three-Kibbutz Cluster

\begin{tabular}{|c|c|c|c|c|c|c|}
\hline Age & $40-49$ & $50-59$ & $60-69$ & $70-79$ & $80-89$ & Total \\
\hline Kibbutzim & 0 & 1 & 2 & 7 & 3 & 13 \\
\hline Kibbutz Pop. & 179 & 128 & 93 & 147 & 45 & 592 \\
\hline $\begin{array}{l}\text { Kibbutz Prev. } \\
(/ 1000)\end{array}$ & 0 & 7.81 & 21.4 & 47.6 & 66.7 & 22.0 \\
\hline $\begin{array}{l}\text { Negev est. } \\
\text { Prevalence } \\
(/ 1000)\end{array}$ & 0.095 & 0.57 & 3.52 & 9.61 & 12.48 & 2.228 \\
\hline Cluster Pr* & 0 & 13.7 & 6.08 & 4.95 & 5.34 & $9.87 \#$ \\
\hline \multicolumn{7}{|c|}{$\begin{array}{l}\text { Expected in kibbutz clusters } \\
\text { based on their population } \\
\text { and Negev rates }\end{array}$} \\
\hline $\begin{array}{l}\text { p for observed } \\
\text { being as great }\end{array}$ & $\begin{array}{l}0.017 \\
\text { alues in cl } \\
y \text { chance }\end{array}$ & $\begin{array}{l}0.073 \\
\text { cluster }\end{array}$ & 0.33 & 1.41 & 0.56 & 2.39 \\
\hline & N.A. 0 & 0.079 & 0.046 & 0.008 & 0.021 & 0.0000024 \\
\hline
\end{tabular}

\section{* Prevalence Ratio}

N.A. - not appropriate

\# This is a crude ratio, not age adjusted. The age adjusted one is 5.43 as shown in the next table. The expected value shown in the line below is the sum of the age-specific expected values, and not the crude one. are shown in Table 1, and the standardized prevalence ratios (SPR) are given in Table 2. As seen from these data and from the histogram (Figure 1), the age specific prevalence in the 3 Kibbutzim is consistently high in comparison with that in the Negev population, indicating a cluster of PD. The Poisson probability for the observed prevalence in the clusters compared to the age-specific rate for the whole Negev is shown in the bottom row of Table 1.

All of the PD patients in kibbutz $A$ and $B$ have lived there for approximately 40 years and in kibbutz $C$ for at least 20 years. All of the patients, as well as the other members of these kibbutzim are Askenazy, born in Central and Eastern Europe, Brazil and Argentina. Our patients immigrated to Israel after the age of 20 .

Eleven of the 13 PD patients were born and lived for at least 15 years in small towns and villages where the water supply was

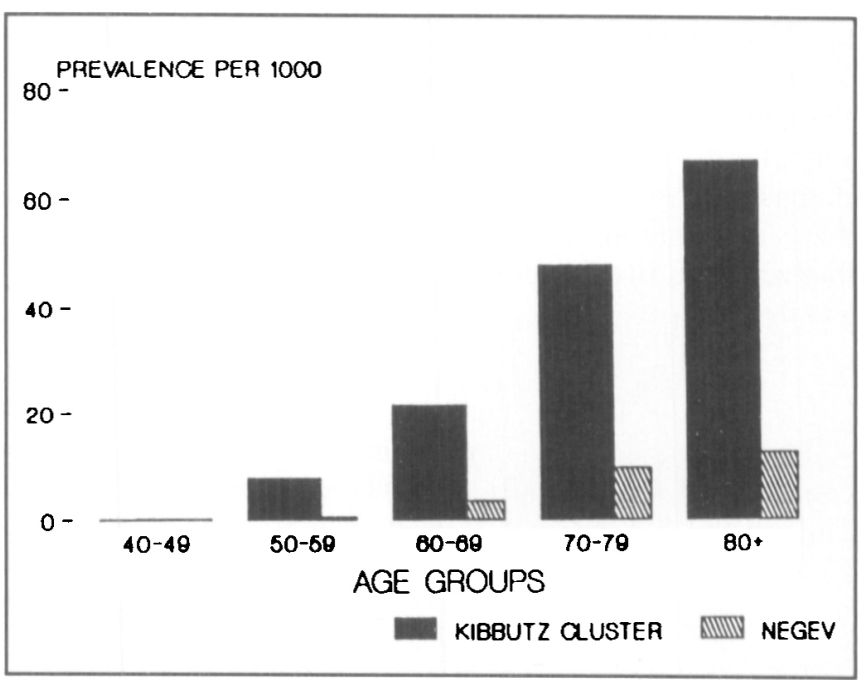

Figure I-Comparative age-specific prevalence of Parkinson's disease in Negev and cluster.

Table 2: Parkinson's Disease by Kibbutz in Cluster of Negev Kibbutzim

\begin{tabular}{|c|c|c|c|c|c|c|c|}
\hline Age & $40-49$ & $50-59$ & $60-69$ & $70-79$ & $80-89$ & Total & Spr* \\
\hline \multicolumn{8}{|l|}{ Kibbutz } \\
\hline Obs. & 0 & 0 & 1 & 5 & 0 & 6 & \multirow{5}{*}{6.16} \\
\hline "A" & & & & & & & \\
\hline Popul. & 59 & 28 & 17 & 76 & 13 & 193 & \\
\hline Exp. & 0.0056 & 0.016 & 0.060 & 0.730 & 0.162 & 0.974 & \\
\hline Obs. & 0 & 0 & 1 & 2 & 1 & 4 & \\
\hline "B" & & & & & & & \multirow[t]{4}{*}{5.37} \\
\hline Popul. & 59 & 18 & 46 & 46 & 10 & 179 & \\
\hline Exp. & 0.0056 & 0.010 & 0.162 & 0.442 & 0.125 & 0.745 & \\
\hline Obs. & 0 & 1 & 0 & 0 & 2 & 3 & \\
\hline "C" C" & & & & & & & \multirow[t]{4}{*}{4.46} \\
\hline Popul. & 61 & 82 & 30 & 25 & 22 & 220 & \\
\hline Exp. & 0.006 & 0.047 & 0.106 & 0.240 & 0.274 & 0.673 & \\
\hline Obs. & 0 & 1 & 2 & 7 & 3 & 13 & \\
\hline \multicolumn{7}{|l|}{ Total } & \multirow[t]{2}{*}{5.43} \\
\hline $\begin{array}{l}\text { Popul. } \\
\text { Exp }\end{array}$ & $\begin{array}{c}179 \\
0.017\end{array}$ & $\begin{array}{c}128 \\
0.073\end{array}$ & $\begin{array}{c}93 \\
1413\end{array}$ & $\begin{array}{c}147 \\
0.562\end{array}$ & $\begin{array}{c}45 \\
2392\end{array}$ & 592 & \\
\hline
\end{tabular}

*SPR - standardized (for age) prevalence ratio

Exp - expected prevalence based on that in all the Negev 
exclusively from wells, before immigrating to Israel. Their mean age at the onset of their disease was 68 years.

One patient showed the first symptoms of PD 11 years ago; the others have had symptoms of PD for 1-6 years. Their clinical condition presented no features distinctive from other PD patients. The presenting neurological sign was resting tremor in 3 patients, akinesia and resting tremor in five patients, and akinesia, resting tremor and rigidity in the other five. None of these patients were under psychiatric care in the last ten years. All of these patients were non-smokers at the time of the onset of their condition, but 4 of the 13 patients had smoked in the past. The PD patients have worked at a variety of occupations, including teaching, clerking, sewing, laundry (4/13), agriculture (6/13), raising cows and sheep and in the local industry, (3/13).

There was no correlation detected between the other responses to the questionnaire and the incidence of PD. These kibbutzim utilize various pesticides, herbicides and fungicides (mainly Maneb) usually spread from light airplanes. The metallurgic factory in A utilizes $\mathrm{Mn}, \mathrm{Zn}$ and $\mathrm{Ni}$.

Only 3 PD patients were detected in the other Kibbutzim and Moshavim (Table 3). The great majority of the founding members of these Kibbutzim were originally from East and Central Europe and from Argentina and entered the kibbutzim close to their immigration date. The people living in the Moshavim immigrated to Israel from North Africa (Egypt, Morocco, Tunis) and from Iraq.

\section{Discussion}

Parkinson's disease is more frequently encountered in the countries of higher latitude, such as Sweden, 7 Scotland, 3 Finland, 8 U.S.A. ${ }^{9}$ A low incidence was found in Sardinia$65.6 / 100,000.1^{1}$ Our study revealed a prevalence rate of PD in the

Table 3: Population Data and Occurrence of Parkinson's Disease in other Kibbutzim and Moshavim in the Negev

\begin{tabular}{|c|c|c|c|c|}
\hline Kibbutz & \# members & $>50 y$ & \#PD & Year founded \\
\hline Magen & 400 & 45 & none & 1949 \\
\hline Zeelim & 350 & 50 & none & 1948 \\
\hline Nirim & 420 & 49 & none & 1948 \\
\hline Kessufim & 411 & 53 & none & 1952 \\
\hline Nir-Am & 280 & 84 & none & 1943 \\
\hline Revivim & 660 & 198 & none & 1943 \\
\hline Mashave-Sadeh & 370 & 92 & none & 1947 \\
\hline Hatzerim & 450 & 130 & none & 1946 \\
\hline Urim & 600 & 147 & none & 1946 \\
\hline $\mathrm{Nir} O z$ & 300 & 63 & none & 1957 \\
\hline Reim & 320 & 79 & none & 1949 \\
\hline Kfar-Aza & 520 & 152 & 1 & 1951 \\
\hline Saad & 730 & 210 & 1 & 1947 \\
\hline Gevim & 350 & 93 & none & 1947 \\
\hline Beeri & 653 & 195 & none & 1946 \\
\hline $\begin{array}{l}\text { Eyn-Hashlosha } \\
\text { MOSHAVIM }\end{array}$ & 380 & 85 & none & 1950 \\
\hline Ranen & 450 & 82 & none & 1950 \\
\hline Peduim & 300 & 70 & none & 1950 \\
\hline Maslul & 251 & 63 & none & 1950 \\
\hline Maabuim & 180 & 42 & none & 1958 \\
\hline Taashur & 220 & 50 & 1 & 1953 \\
\hline Paamei Tashaz & 280 & 62 & none & 1953 \\
\hline Nir Moshe & 298 & 72 & none & 1953 \\
\hline Sade Zwi & 330 & 92 & none & 1953 \\
\hline
\end{tabular}

Negev of $62.1 / 100,000$. If the 13 cluster cases are omitted along with the estimated 3,000 kibbutz residents, the net prevalence rate would be $57.9 / 100,000$.

The etiology of Parkinson's disease is still unknown. The epidemiological studies done in various geographical locations show that this condition is more frequent in rural populations, $5,6,7$ and since the main water supply in these regions is from wells, well-water has been incriminated $5,6,7$ as playing a role in the development of the disease. For example, Rajput et al $^{5}$ found that 19 out of 21 Parkinsonian patients under the age of 40 in Saskatchewan lived their first 15 years in rural areas and 18 of them utilized well water. Schoenberg 7 arrived at a similar conclusion. Barbeau et $\mathrm{a}^{6}$ have studied a rural population relatively homogeneous for genetic attributes who worked as market gardeners. This work involves high intensity pesticide usage and they found a high incidence of PD. The thesis ${ }^{10}$ that pesticides and/or herbicides play a role in the etiology of Parkinson's disease in rural regions is supported by the fact that paraquat ${ }^{11}$ a commonly used herbicide has a chemical structure similar to that of MPTP, the synthetic narcotic known to produce a parkinson syndrome, clinically similar to Parkinson's disease. 12

In our study we found a clustering of patients with Parkinson's disease in three adjacent collective rural communities in a limited area of the Negev. Very few other cases were found scattered between other kibbutzim and moshavim (villages) in the Negev, where there were similar living conditions. The population of these kibbutzim, including all of the patients, is Askenazy. Most of the PD patients consumed well water inhabiting the kibbutzim and have continued to use well water along with other residents of the kibbutzim.

The occupations of these PD patients do not differ from other kibbutz members in the Negev. It is possible that environmental factors specific for these three kibbutzim acted on people with a predisposition to develop the disease. We suggest that these factors start their influence after the age of 20 and not before, as proposed by Rajput et al, ${ }^{5}$ since our patients immigrated from different countries after this age. These kibbutzim utilize a wide variety of herbicides, pesticides and fungicides which are spread mostly from airplanes and could contaminate the water supply. One of these compounds is Maneb (manganese ethylene-bisdithiocarbamate) an organomanganese compound widely used as a fungicide for protection of edible crops in market gardening regions. Recently, a study from Brazil13 on a group of rural workers exposed to this compound, showed a significantly higher prevalence of cogwheel rigidity, memory disturbances and sleepiness. The population of these kibbutzim is exposed to paraquat and to carbon disulfide. The latter, a fumigant, was recently incriminated 14 in production of an atypical parkinsonism, cerebellar signs, hearing loss and peripheral sensory changes. Since these kibbutzim are not the only ones using these compounds, it is possible that these, and presumably other factors present in the environment, act in conjunction with the natural aging process and a genetic predisposition to induce the pathological changes of Parkinson's disease in our patients.

\section{REFERENCES}

1. Rosati G, Granieri E, Pinna L, Aiello I, et al. The risk of Parkinson's disease in Mediterranean people. Neurology 1980; 30: 250-255. 
2. Harada H, Nishikawa S, Takahashi K. Epidemiology of Parkinson's disease in a Japanese city. Arch Neurol 1983; 40: 151-154.

3. Mutch WJ, Dingwall-Fordyce I, Downie AW, Paterson JG, Roy SK. Parkinson's disease in a Scottish city. Br Med J (Clin Res) 1986; 292: 534-536.

4. Calne DB, Langston JW. Aetiology of Parkinson's disease. Lancet II $1983 ; 1457-1459$.

5. Rajput AH, Uitti RJ, Stern W, Laverty W. Early onset Parkinson's disease in Saskatchewan-environmental considerations for etiology. Can J Neurol Sci 1986; 13: 312-316.

6. Barbeau A, Roy M, Bernier G, Campanella G, Paris S. Ecogenetics of Parkinson's disease: prevalence and environmental aspects in rural areas. Can J Neurol Sci 1987; 14: 36-41.

7. Schoenberg BS. Environmental risk factors for Parkinson's disease: the epidemiologic evidence. Can J Neurol Sci 1987; 14: (Suppl 3) 407-413.

8. Martila RJ, Rinne VK. Epidemiology of Parkinson's disease in Finland. Acta Neurol Scand 1976; 53: 82-102.
9. Kessler II. Parkinson's disease in epidemiologic perspective. In: Shoenberg B.S., ed. Adv. in Neurology Vol. 19, 1978; 355-384.

10. Barbeau A. Etiology of Parkinson's disease: a research strategy. Can J Neurol Sci 1984; 11:24-28.

11. Bocchetta A, Corsini GV. Parkinson's disease and pesticides. Lancet II 1986; 1163.

12. Langston JW, Ballard P, Tetrud JW, Irwin I. Chronic parkinsonism in humans due to a product of meperidine-analog synthesis. Science 1983; 219: 979-980.

13. Ferraz HB, Bertolucci PHF, Pereira JS, Lima JGC, Andrade LAF Chronic exposure to the fungicide maneb may produce symptoms and signs of CNS manganese intoxication. Neurology 1988; 38: 550-553.

14. Peters HA, Levine RL, Mattews CG, Chapman LJ. Extrapyramidal and other neurologic manifestations associated with carbon disulfide fumigant exposure. Arch Neurol 1988; 45: 537-540. 